\title{
Maricélia de Almeida Vieira
}

\section{QUALIDADE DE VIDA NO TRABALHO E FATORES DE IMPACTO NAS PROFISSÕES ENA}

$$
\begin{gathered}
\text { Saúde } \\
\text { dos } \\
\text { Trabalhadores }
\end{gathered}
$$




\section{Maricélia de Almeida Vieira}

\section{QUALIDADE DE VIDA NO TRABALHO E FATORES DE IMPACTO NAS PROFISSÕES ENA}

$$
\begin{gathered}
\text { Saúde } \\
\text { dos } \\
\text { Trabalhadores }
\end{gathered}
$$




\section{CONSELHO EDITORIAL}

Prof. Dr. Adilson Tadeu Basquerote

Silva

UNIDAVI/SC

http://lattes.cnpq.br/8318350738705473

Profa. Msc. Jesica Wendy Beltrán

UFCE- Colômbia

http://lattes.cnpq.br/0048679279914457

Profa. Dra Fabiane dos Santos Ramos UFSM- Santa Maria/RS

http://lattes.cnpq.br/0003382878348789

Dr. João Riél Manuel Nunes Vieira de Oliveira Brito

UAL - Lisboa- Portugal.

http://lattes.cnpq.br/1347367542944960

Profa. Dra. Alessandra Regina Müller Germani

UFFS- Passo Fundo/RS

http://lattes.cnpq.br/7956662371295912

Prof. Dr. Everton Bandeira Martins

UFFS - Chapecó/SC

http://lattes.cnpq.br/9818548065077031

Prof. Dr. Erick Kader Callegaro Corrêa UFN- Santa Maria/RS

http://lattes.cnpq.br/2363988112549627

Prof. Dr. Pedro Henrique Witchs

UFES - Vitória/ES

http://lattes.cnpq.br/3913436849859138

Prof. Dr.Thiago Ribeiro Rafagnin

UFOB

http://lattes.cnpq.br/3377502960363268
Prof. Dr. Mateus Henrique Köhler

UFSM- Santa Maria/RS

http://lattes.cnpq.br/5754140057757003

Profa. Dra. Liziany Müller

UFSM- Santa Maria/RS

http://lattes.cnpq.br/1486004582806497

Prof. Dr. Camilo Darsie de Souza

UNISC- Santa Cruz do Sul/RS

http://lattes.cnpq.br/4407126331414

Prof. Dr. Dioni Paulo Pastorio

UFRGS - Porto Alegre/RS

http://lattes.cnpq.br/7823646075456872

Prof. Dr. Leonardo Bigolin Jantsch

UFSM- Palmeira das Missões/RS

http://lattes.cnpq.br/0639803965762459

Prof. Dr. Leandro Antônio dos Santos

UFU- Uberlândia/MG

http://lattes.cnpq.br/4649031713685124

Dr. Rafael Nogueira Furtado

UFJF- Juiz de Fora/MG

http://lattes.cnpq.br/9761786872182217

Profa. Dra. Angelita Zimmermann

UFSM- Santa Maria/RS

http://lattes.cnpq.br/7548796037921237

Profa. Dra. Francielle Benini Agne

Tybusch

UFN - Santa Maria/RS

http://lattes.cnpq.br/4400702817251869

Copyright (C) Arco Editora, alguns direitos reservados.

Copyright do texto (c) 2022 os autores e as autoras.

Copyright da edição (C) 2022 Arco Editora. 
Diagramação e Projeto Gráfico : Gabriel Eldereti Machado

Revisão: dos/as autores/as.

Dados Internacionais de Catalogação na Publicação (CIP) (Câmara Brasileira do Livro, SP, Brasil)

Vieira, Maricélia de Almeida
Qualidade de vida no trabalho e fatores de
impacto nas profissões e na saúde dos trabalhadores
[livro eletrônico] / Maricélia de Almeida Vieira. --
Santa Maria, RS : Arco Editores, 2022.
PDF
Bibliografia
ISBN 978-65-89949-71-8
1. Dignidade humana 2. Qualidade de vida no
trabalho 3. Relações humanas 4. Segurança no trabalho
T. Título.
22-101255 CDD-363.11

Índices para catálogo sistemático:

1. Qualidade de vida no trabalho : Saúde e segurança : Bem-estar social 363.11

Maria Alice Ferreira - Bibliotecária - CRB-8/7964

\subsection{9/978-65-89949-71-8}

O padrão linguístico-gramatical, bem como o sistema de citações e referências bibliográficas são prerrogativas de cada autor. Da mesma maneira, o conteúdo e teor de cada capítulo é de inteira e exclusiva responsabilidade de seu respectivo autor. 
Agradecimentos a professora Ma. Caroline L. Rohde que estabeleceu uma caminhada na construção da orientação da pesquisa em 2018, com o título "A saúde do trabalhador e a qualidade de vida no trabalho, na representação em contos", que possibilitou ampliar para construir este livro. 


\section{PREFÁcio}

Como professor universitário e magistrado de direito ocupo-me prioritariamente, desde a minha formação, cultural e acadêmica, com a dignidade humana, em todas as dimensões abarcadas pelo conceito filosófico e abstrato, mas sobretudo no seu valor como princípio fundamental em todas as relações humanas.

Embora muitos considerem as dificuldades da sua aplicabilidade na prática, acredito na possibilidade de que o princípio da dignidade humana deva reger o mundo da vida, este que, Edmund Husserl (1986) compreende de modo ímpar, como o mundo natural - na atitude da vida natural; "somos sujeitos vivos atuantes junto a outros sujeitos atuantes em um círculo aberto".

Compreendo a dignidade humana para além de conceito abstrato, fluindo no cotidiano do mundo da vida, da vida compartilhada com outros sujeitos, na qual todos atuam como pertencentes a um mundo comum. Todo ser humano é valioso e igual e suas diferenças são a riqueza multi e intercultural que torna a humanidade singular.

Este conceito e princípio procede do lluminismo, influenciando o pensamento que movimentou as revoluções burguesas, como a Revolução Francesa, demarcando o início da Idade Moderna com os ideais de Liberdade, Igualdade e Fraternidade.

O ordenamento jurídico brasileiro reconhece a dignidade humana como princípio, sendo um dos fundamentos do Estado Democrático de Direito, previsto no artigo $1^{\circ}$, inciso III, da Constituição da República Federativa. O Princípio da Dignidade Humana será também encontrado no artigo $1^{\circ}$ da Declaração Universal dos Direitos Humanos e no artigo $5^{\circ}$ da Convenção Interamericana de Direitos Humanos.

O convite honroso para prefaciar a obra de Maricélia de Almeida Vieira, "Qualidade de vida no trabalho fatores de impacto nas profissões e na saúde dos traba- 
Ihadores", representa oportunidade ímpar para analisarmos o princípio da dignidade humana aplicado ao mundo da vida e do trabalho. O leitor atento perceberá essa preocupação na transversalidade da obra, produzida a partir da Análise Qualitativa de Conteúdo (BARDIN, 2010).

De modo inusitado, a autora escolhe cinco contos e organiza uma casuística para trazer à tona a questão da Qualidade de Vida no Trabalho - QVT, premissa que permeia a gestão de pessoas, porém nem sempre é efetivamente regida por um Programa de qualidade de vida e bem-estar dos trabalhadores.

Não havemos de estranhar que ainda no Século XXI este tema abordado na obra seja em muitos aspectos uma abstração teórica. Desde os primórdios, o trabaIho, como atividade humana consciente, vem acompanhando a história - por ela e com ela, desenvolveu-se a cultura e, pari passu com a linguagem.

Ainda na pré-história surgiram as primeiras atividades agrícolas. Nas várias civilizações, o homem e o mundo laboral passam a se constituir a partir do interesse dominante: no Egito Antigo, a servidão coletiva; na Grécia Antiga, a escravidão; na Alta Idade Média, o feudalismo, regime restrito de servidão entre os senhores feudais e seus vassalos.

Na Europa, com a Revolução Industrial, a partir do século 17 surge a venda da força de trabalho por remuneração. E surge também a necessidade de especialização das forças de trabalho, desenvolvendo-se as habilidades técnicas, a relação entre as pessoas e a busca por objetivos econômicos e sociais.

$\mathrm{Na}$ atualidade, em meio à crise econômica que afeta parte importante da população e acirrada pela pandemia que nos atinge globalmente, vivemos momentos de incertezas e mobilização pela saúde planetária.

A qualidade de vida no trabalho levanta várias possibilidades de análise. $\mathrm{Na}$ direção de criar, manter e melhorar o ambiente de trabalho, com condições físicas, psicológicas e sociais, com vistas a um ambiente agradável e amigável nas organizações, surge a importância do conceito de ambiência laboral. 
Ambiência como condições favoráveis à dignidade humana, quanto às dimensões objetivas, subjetivas e intersubjetivas. Laboral, reportando à palavra labor, do latim antigo "labore", que significava trabalho, tarefa, labuta, antes de que se atribuisse o sentido de pesaroso. Ao pensar na importância de uma ambiência laboral que se constitua a partir da qualidade de vida e bem-estar dos trabalhadores, se estabelece um divisor de águas, entre a servidão coletiva, a escravidão e o feudalismo, cujos traços ainda sobrevivem no DNA de algumas empresas que visam ao lucro pelo lucro.

A qualidade de vida no trabalho encontra-se na interface do mundo da vida, do trabalho e das organizações. A representação humana, a saúde do trabalhador e a qualidade de vida no trabalho e existência de cada indivíduo no mundo das organizações, requer que se pense em novas propostas para uma gestão colaborativa entre as pessoas e com várias situações do contexto do trabalho.

A autora analisa com perspicácia que, além das demandas típicas do mundo do trabalho, o gestor que promove momentos de diálogo pode representar a mudança esperada, incluindo formas de subjetivação e bem-estar por pertencimento ao contexto da organização, imprimindo o pertencimento de modo natural aos participantes e colaboradores no grupo da empresa ou da instituição.

As condições de vida se apresentam no percurso da trajetória da pessoa, iniciando muitas vezes uma nova experiência de si e (auto) orientação, desenvolvendo no processo de favorecimento social, múltiplas possibilidades para as tomadas de consciência, a exemplo do que analisa Marie-Christine Josso (2004). Chamou-me à atenção no conto "Faixa Preta" (BARBOSA, 2003), a declaração de um Comandante Aviador aposentado, ao analisar seu momento pós-aposentadoria: 
to, todos olham com admiração os tripulantes. Sempre bem arrumados, penteados, (...). Os anos voaram na velocidade dos aviões. Esqueci que ia envelhecer e que teria que dar adeus àquilo tudo que ainda me envolvia $[\ldots]$.

Estava este "trabalhador do ar" preparado para a aposentadoria? Esta pessoa foi feliz ao longo do seu tempo no mundo do trabalho. E agora, onde se encontra a sua felicidade? Com certeza não a encontrará nos medicamentos de faixas pretas que toma para se manter minimamente em um bem-estar artificial. Perdeu a sua dignidade ao aposentar-se, talvez porque o mundo da vida, o mundo do trabalho e a organização fossem fragmentos a impor-lhe respostas de pronto. São essas situações que a obra, no seu conjunto, nos traz como reflexão pertinente que nos leva à autorreflexão da nossa própria condição humana.

A obra é, pois, um chamamento a um novo olhar à pessoa do trabalhador, em três níveis: biológico, psicológico e o social. Biológico, incluindo a identidade pessoal, características inatas ou adquiridas ao longo do tempo, metabolismo, vulnerabilidades e resistências físicas. Psicológico, integrando os processos emocionais, afetivos e de pensamentos, conscientes e inconscientes que moldam a personalidade e o modo de perceber e se relacionar com as pessoas e o mundo. O nível social, com os valores, as crenças e a forma de participação do indivíduo em todos os grupos de que faz parte (FERREIRA, 2013). Neste parágrafo, faz sentido as categorias de análise que permitiram o mergulho nos contos: relacionamentos humanos, percepções da qualidade de vida, saúde do trabalhador e comprometimento com a empresa.

Finalmente, ao destacar os professores a partir do texto narrativo, a autora mobiliza o leitor a pensar em todos os profissionais formados pela/na/a partir da escola, nos diferentes contextos sociais e situações que representam a formação e capacitação humana. Valoriza as profissões e profissionais no mundo do trabalho, com a face do marceneiro, do soldador, do aviador, do administrador, 
do médico, entre outras, como uma ideia de formação de processo final, e de desenvolvimento reconhecido pelo mercado de trabalho. Mas sempre, com a escola no início de tudo.

Leitura prazerosa, leve e informativa. Fica o convite ao leitor.

Em Santa Maria, RS, Brasil, janeiro de 2022.

Ulysses Fonseca Louzada 


\section{PRIMEIROS}

\section{MOMENTOS}

NARRATIVOS 
A saúde e a qualidade de vida do trabalhador representados pela construção e na elaboração da produção textual em narrativas através dos contos, demostra a sua importância na proposta de narrar histórias e vivências no mundo do trabalho. Os contos podem demandar uma proposta de ficção na questão da narrativa, mas a diversidade de temáticas aborda os fatos dos sujeitos que trabaIhavam em diferentes locais e profissões.

As obras que estão citadas no corpo de trabalho, para a proposta de reflexão, ampliaram os entendimentos das concepções de sujeitos associados ao mundo do trabalho. O referencial teórico tende a dar o suporte acadêmico para aprofundamento e valorização dos sujeitos trabalhadores.

Desta forma, ao estabelecer normas para reflexão de temas como saúde do trabalhador, qualidade de vida no trabalho e as profissões que demandam estado emocional dos sujeitos, gerou muitos questionamentos e indagações tal a seriedade deste tema na atualidade.

A proposta deste livro proporciona pensar na vida atual e das demandas que muitos acontecimentos trouxeram novas impressões de trabalho. Na proposta de contos faz com que as narrativas mostrem uma leveza na literatura, demandando seriedade para reorganizar assuntos e acontecimentos de saúde do trabalhador, visto que a sua importância é de ordem mundial.

\section{Boa leitura!}


"Ao organizar a escrita deste livro, procurei pensar nas possibilidades em colaborar com leitores que vivenciam as histórias narrativas da vida no trabalho". (a autora)

No início do século XVIII ocorreram inúmeras transformações nos processos industriais. A população mundial crescia aceleradamente, o mercado consumidor estimulava a produção em diferentes escalas e induzia o aprimoramento tecnológico. A mão de obra tornava-se abundante em relação ao crescimento populacional dando oportunidade para as pessoas do campo e da cidade. Neste ideal de avanço entre o trabalho e a saúde do trabalhador, tornava-se necessário pensar em qualidade de vida nas organizações. Desta maneira, em relação ao conceito de trabalho e dos trabalhadores, existem opções que demandam novas mudanças e um crescimento de exigências do mundo globalizado (BORGES; MOURÃO, 2013).

Nesse sentido, o trabalho é uma atividade que acarreta o confronto do homem com a natureza, faz parte da experiência do humano com mundo, orientada para um fim, ou seja, trata-se de uma atividade realizada para se produzir alguma coisa, de outra forma, pode ser sem a intervenção do sujeito. Neste aspecto, o trabalho vem modificando as pessoas no contexto pessoal e organizacional, na realização de importantes tarefas, transformando tanto no âmbito familiar como no local de trabalho (BENDASSOLLI e MALVESSI, 2013).

Partindo desta explanação, percebo a importância de identificar alguns aspectos que envolvem as representações no trabalho, visando compreender e transformar, a fim de buscar novas identificações, de modo a ampliar e melhorar a qualidade de vida no trabalho identificados nos contos. 
Assim, foram estudados, em cinco contos extraídos aleatoriamente de duas obras, os fatores que afetam a saúde do trabalhador e a qualidade de vida, e de que forma ocorre o enfrentamento no mundo do trabalho, com relação à subjetividade do indivíduo.

Ainda, percebo quanto à questão de gêneros literários, os livros de contos podem ser lidos e entendidos como um conjunto de histórias orais do cotidiano. Por isso, o gênero conto, produzido nas obras em análise e no interior do campo literário, configura-se materialmente como narrativa artística pouco extensa e, por isso, tem a característica central de condensar conflitos, tempo e espaço, reduzindo o número de personagem. Apesar da tradição folclórica, o conto literário assumiu autor individualizado, e ganhou novos temas e novas formas, de modo que a plasticidade do tema ampliou a relação ao conteúdo temático, à composição, mas principalmente ao estilo (FERRAZ, 2014).

O conteúdo temático de um gênero aponta uma finalidade do discurso ou o próprio entendimento comunicativo. Desse modo, considero que o conteúdo temático do gênero pode ser modificado, principalmente pelas escolhas da comunidade em que se envolvem a circulação dos contos, tendo em vista as crenças, os conceitos éticos, a cultura, e as vivências de cada sujeito, visando assumir propósitos moralizantes ou apenas divertimento, para as pessoas envolvidas no contexto (BAKHTIN, 2010).

Com base nas análises dos contos selecionados, identificou-se, mais especificamente no contexto literário, se os fatores do cotidiano do trabalho afetam a saúde do trabalhador, a qualidade de vida e o enfrentamento, representados nos contos selecionados.

É importante ressaltar que o estudo tende a tratar e analisar as possíveis imbricações entre o trabalho e a vida pessoal dos executivos, funcionários, ope- 
rários de diferentes funções, representados nos contos narrativos e, também, a representação da qualidade de vida neste contexto literário. Além do problema de pesquisa central, uma questão específica também norteou o desenvolvimento, pela análise de que forma identificamos nos cinco contos narrativos, a representação humana, a saúde do trabalhador e a qualidade de vida no trabalho e pessoal de cada indivíduo no mundo das organizações?

Nesta perspectiva justifica-se ampliar as discussões científicas e teóricas que possam identificar o entendimento dos conceitos de qualidade de vida no trabalho, na perspectiva literária dos sujeitos envolvidos nas suas narrativas de vida pessoal, pois as pressões e estresse no mundo do trabalho, certamente, necessitam de maior reflexão e enfrentamento nas questões da vida contemporânea.

Desta forma, outros fatores que contribuem para a investigação, são fundamentais com a elucidação as teorias de autores recentes e atuais sobre qualidade vida e saúde do trabalhador, para estudos em comportamentos na organização de trabalho, e identificar, nos contos selecionados, como se apresentam os fatores de risco e os fatores de proteção na relação pessoa-trabalho, a questão da saúde do trabalhador e da qualidade de vida no contexto organizacional. 


\section{OS MOMENTOS}

\section{DE CONSTRUÇÃO}

NARRATIVA 
Em quase todas as línguas europeias, o trabalho apresenta diferentes significações, sendo que a língua grega tem diferentes formas de utilizar a palavra que pode ser uma para a fabricação e outra, esforço, sendo oposto a ócio. O latim distingue entre laborare, a ação do labor, e operare, o verbo opus, que significa obra. Na língua portuguesa, apesar de haver Labor e trabalho, encontra-se trabalho com diferentes significações, ou seja, a de realizar uma obra que tenha expressão, e a outra forma de repetição, sem liberdade, de resultado consumível (ALBORNOZ, 1994).

Com isso, o termo trabalho tem outros significados que supões tendências para um fim e esforço, para uns, esforço físico, intelectual e corporal. Deste modo, alguns séculos ocorreram muitas descobertas como a invenção da máquina a vapor que foi considerada a revolução tecnológica do século XVIII. O surgimento da tecnologia moderna, no século XIX, caracterizando o uso da eletricidade e da automação, e o que representa o estágio mais recente da evolução tecnológica com o computador, em pleno século XX, na Revolução Industrial (ALBORNOZ, 1994).

Neste sentido, historicamente Couto (1995) citado por Rohde (2012), constata que a fundação da Comissão de Saúde dos Trabalhadores na Indústria de Munições, ocorreu na Primeira Guerra Mundial, foi composta por fisiologistas e psicólogos que criaram em virtude das condições de saúde do trabalhador. No final do pós-guerra ocorreu a transformação no Instituto de Pesquisa sobre Saúde no Trabalho que, algum tempo depois ocorreram pesquisa referentes a posturas no trabalho, a carga manual e forma de seleção treinamentos e a questão de ambiente. Por isso, a questão histórica é imprescindível para ampliar as considerações sobre os conceitos de trabalho, na proposta de pesquisa, como também, as questões sociais atuais.

No entanto, encontro outra concepção de trabalho, teoria concebida pelo engenheiro Taylor, trabalho "taylorizado" ou "taylorismo", que era uma proposta 
de controlar o trabalho das pessoas, monitorando o trabalho, segundo o tempo de produção. Outro momento histórico se deu com o Fordismo, a relação da produção em massa dos funcionários, ou seja, quanto mais remunerado o funcionário, maior o consumismo em massa (ZANELLI, 2014).

Esses aspectos de concepção de trabalho "taylorizado" cuja forma de organizar se torna tão rígido, que domina não somente a vida das pessoas por horas de trabalho, seja na linha de produção, no escritório, nos bancos, ou em outras formas de trabalho repetitivo ou intelectual, que invade a vida das pessoas fora do trabalho, introduzindo aspectos patológicos na vida do trabalhador (DEJOURS, 2015).

Na sociedade patriarcal, supostamente garantindo uma inevitável história de economia determinada e desregulada pela defasagem das fábricas fordistas, surge uma nova flexibilidade dos padrões de emprego e rotinas de trabalho, e de um desmantelamento gradual dos instrumentos de proteção e autodefesa dos trabalhadores. Dessa forma, as mudanças nas relações de empregabilidade mudaram com a competitividade entre indivíduos, lutando para que os chefes os percebessem e os contemplassem, de forma a aprovar suas próprias iniciativas, tornando, assim, lucro para as empresas (BAUMAN, 2005).

Contudo, os trabalhadores nas práticas diárias de suas funções necessitam de tempo para descanso. Nesta relação de fragilidade, novas concepções propunham a conceituar este momento do Taylorismo como "vadiagem" no local de trabalho, não sendo considerados momentos de descanso e repouso, nem mesmo que se "intercalavam no trabalho, mas as fases que os operários trabaIhavam em ritmo menor do que poderiam ou deveriam executar ou adotar" na organização (DEJOURS, 2015, p. 46).

No entendimento de Bendassolli (2013), o trabalho tende a ser visto como uma atividade orientada para um fim, pois trata-se de uma atividade realizada 
para se produzir alguma coisa que, de outra forma, sem a intervenção do sujeito, poderia não existir. Neste sentido, o trabalhador é um agente que exerce força de diferentes formas, sobre a construção e finalização de uma produção ou serviço em um mercado ou uma sociedade.

Porém, o trabalhador tende a dar continuidade do seu trabalho fora da organização, pois a contaminação do tempo perpetua no momento de vida pelo comportamento que "condicionado ao comportamento produtivo pela organização do trabalho, ele conserva a mesma pele e a mesma cabeça, pois ele é um ser único e inteiro". Desta forma, dentro e fora do trabalho ocorre um contínuo dificilmente dissociável (DEJOURS, 2015, p. 58).

Assim, o momento histórico do fordismo, propunha que os funcionários fossem pagos com altos salários, e as mudanças de estilo de vida provocadas pela Ford, com o objetivo de elencar a produção e manter afastado o funcionário dos sindicatos. Em virtude de abordagens integrativas do (taylorismo e do fordismo) ocorre uma renovação e reafirmação a concepção capitalista tradicional do trabalho, negando o antagonismo da obra marxista, ou seja, luta de classes (BENDASSOLLI, 2013).

No entanto, no período pós-industrial, surge um momento de reflexão social sobre a qualidade de vida como algo importante ou, ainda, um modismo social. Nos efeitos sociais deste momento, possibilitou realizar o aumento do conceito de qualidade de vida, um maior tempo de trabalho em atividades de produção, maior consciência do trabalho e dos direitos à saúde, apelos a novos hábitos e estilos de comportamentos, responsabilidade social e consolidação do compromisso de desenvolvimento sustentável. Dessa maneira, as questões de (QVT) remonta reflexões sobre questões das pessoas no cotidiano das organizações e a vida no trabalho, de modo a atingir e modelar interativamente pessoas e instituições de qualquer tipo (FRANÇA, 2010). 
Devido às transformações que ocorreram ao longo das questões históricas relacionadas ao conceito de QVT porque as atividades das empresas preocuparam-se com a atribuição dos títulos de programas que tornaram o conceito muito simplista e com uma visão reducionista, relativizando apenas o comportamento humano nas organizações, motivando apenas a expressão com poucos significados na área dos recursos humanos (FERNANDES, 1996). 


\section{OS TRABALHADORES}

E $O$ MUNDO DO TRABALHO 
A questão do processo de industrialização que vem ocorrendo desde o Século XIX, tem impactado o modo e o estilo de vida das pessoas, o distanciamento do homem com a natureza e de hábitos poucos saudáveis de vida, valorizando apenas a aquisição de bens e produtos, conforto e praticidade. Nestas condições surgem inúmeras doenças relacionadas ao processo da civilização decorrentes de tensões emocionais e psicológicas e que possibilitam ambientes estressantes no trabalho (MOSER; KERBING, 2006).

Além do trabalho em excesso e da busca permanente por sucesso, os indivíduos também podem se desestruturar psicologicamente, tendo consequentes problemas de saúde, como estresse e ansiedade, levando, muitas vezes, ao consumo excessivo de droga ilícitas e lícitas, como o álcool. O uso do drogas pode ser uma das consequências que gera maiores dificuldades e adoecimento no mundo do trabalho, pondo em risco a vida do trabalhador. No propósito de destacar das demais pessoas do grupo como herói a ser seguido, a fantasia cai por terra quando sobram problemas para o indivíduo, comprometendo não só a saúde como também o relacionamento com as outras pessoas (SIQUEIRA, 2009).

Há ainda as questões em que os sentimentos de desequilíbrio entre vida e trabalho, de isolamento e/ou de não pertencimento ao grupo, de conflito de valor, de ausência de prazer, de medo, de que o trabalho não tem valor ou utilidade etc., sendo todos entendidos como "alarme" (CARDOSO, 2015).

A preocupação no contexto da organização ocorre de forma acirrada e competitiva que transforma o ambiente de trabalho, sendo que o indivíduo se deixa levar por um processo dominador com sua permissão, de modo incontestável e sem limites (SIQUEIRA, 2009).

Na realidade atual, as empresas criam estratégias que exige dos trabalhadores cada vez mais momentos disponíveis na empresa, seja por meio de flexibilização do tempo de trabalho, seja por sua ampliação velada, possibilitada pela tecnologia de comunicação (CARDOSO, 2015). 
Os indivíduos nas organizações utilizam diferentes tecnologias de comunicação, sendo que as informações demandam atenção plena nas leituras de e-mails, chats online, programa de computador, celular, textos, tabelas, planilhas etc. Ainda que a multitarefa possa dar sensação ao indivíduo de produtividade, algumas pesquisas recentes apontam que pessoas envolvidas em muitas multitarefas têm dificuldades em manter o foco, durante e após a finalização da tarefa (SARTIN e KATSAROU, 2012).

Limongi-França (2010) afirma que a expressão Qualidade de Vida no Trabalho tem sido usada para descrever valores relacionados ao contexto e a experiência humana no ambiente de trabalho. Em virtude deste entendimento, noto que a subjetividade é essência, um estado da mente que influencia em muitos fatores referentes ao mundo do trabalho e a personalidade do trabalhador.

Além das demandas do mundo do trabalho, o sujeito responsável ou o gestor que proporciona momentos de diálogo, pode representar verdadeiras formas de subjetivação e bem-estar por pertencimento ao contexto da organização, favorecendo com que muitos participantes e trabalhadores possam se sentir pertencentes ao grupo da empresa ou da instituição.

Desta forma, o diálogo e o pertencimento nas instituições representam um momento essencial na produção de processos que "se tornam reais o processo de democratização", centralizado no desenvolvimento da instituição e, também, os seus membros (REY, 2004, p.47).

Para Siqueira (2009, p. 202), muitas vezes, o indivíduo está preocupado em ser um profissional admirado, criativo e com alta capacidade de realização, independentemente do modo que possa ser conseguido atingir o mérito, sendo este uma espécie de contrato com a empresa, com a possibilidade de retornos significativos, tais como trocas de dinheiro, poder e prestígio, mesmo que, "para a busca do sucesso profissional, abra mão de tudo, inclusive de sua saúde." 


\section{O MUNDO DO}

\section{TRABALHO E}

AS RELAÇÕES

DE ESTRESSE 
A palavra "estresse" para muitas pessoas possui significado de pressão e, quando ocorre o estresse, o estágio ultrapassa o limite de pressão.

Desta forma, o estresse é cumulativo e quando maior o tempo de estresse que os indivíduos sofrem, mais patologias e doenças físicas. Quando o trabalhador é tomado por níveis de estresse, a possibilidade é maior de ter um colapso e obrigado a reduzir drasticamente o desempenho no trabalho (SARTIN; KATSAROU, 2012).

A maioria dos trabalhos envolve situações consideradas pelos funcionários como estressantes, pelo poucos prazos e tempo, bem significativos na resolução das atividades diárias. Desta forma, o estresse ocupacional possui fatores que levam ao desgaste emocional no trabalho, sendo este uma reação negativa em funcionários através da raiva, ansiedade ou um sintoma físico, como uma dor de cabeça ou outra fisiológica. Os desgastes podem ser categorizados em reações psicológicas, reações físicas e reações comportamentais. Para Spector (2014), o desgaste de trabalho dos funcionários apresenta as seguintes situações no contexto de trabalho:

As reações psicológicas envolvem reações, tais como ansiedade, frustração, raiva, insatisfação no trabalho;

As reações físicas incluem sintomas como dores de cabeça, tontura, palpitações, enfermidades, dor de estômago, doenças como o câncer;

As reações comportamentais são reações aos fatores estressantes no trabalho e incluem uso de drogas, tabagismo, acidentes e comportamentos contraproducente no trabalho (SPECTOR, 2014, p. 309).

Nesta perspectiva, o contexto de trabalho pode promover situações de grande insatisfação e desconforto, sendo um gatilho emocional para os indivíduos acarretarem relações sintomáticas adversas. (SIMIONATO, 2011). 
$\mathrm{Na}$ vida profissional ou no contexto de trabalho, qualquer indivíduo está sujeito ao envolvimento frenético da jornada de trabalho, sendo esta ignorada. Com isso, haja vista a capacidade de lidar com desafios, pressão, estresse e angústia, o aprendizado torna-se fundamental para não enfraquecer o sistema imunológico. Quando os desafios estão começando a afetar o cotidiano, pode ser detectado alguns indicadores apontados por Hoverd (2015):

$\checkmark$ dificuldade para dormir e cansaço ao acordar;

$\checkmark$ mais cansaço que o habitual;

$\checkmark$ emoções à flor da pele;

$\checkmark$ dificuldade de concentração ao executar tarefas;

$\checkmark$ baixo nível de energia em determinados momentos do dia;

$\checkmark$ impaciência ou frustração, evidenciada na resposta, aos outros.

Desta forma, os desafios geram alguns desgastes nas tarefas que reduzem a capacidade de atender as demandas do trabalho (HOVERD, 2015, p. 16). Além disso, na concepção de Dejours (2015), o sofrimento invisível, mesmo intenso, é controlado pelas estratégias defensivas, que impedem a transformação patológica. Além disso, as neuroses, psicoses e depressões se tornam inevitáveis no contexto do trabalho intenso e, ao ser identificado pela organização, podem ser imediatamente retiradas do contexto organizacional.

Um fator de solução para isso é o absenteísmo e descompensação psiconeurótica; podem ser proibidos no trabalho, ou seja, não podem abandonar a função sem explicações e retirar-se do contexto de trabalho. Entretanto, a consulta médica encobre um sofrimento mental que desloca para o uso da medicalização e o afastamento do trabalho. Logo, os ritmos de trabalho são possíveis de solucionar tais como: "largar o trabalho, trocar de posto ou mudar de empresa, sendo 
consideradas fórmulas que podem encobertar a alta rotatividade" (DEJOURS, 2015, p.158).

Para tanto, o comportamento concreto não constitui uma expressão acabada e absoluta de nenhuma unidade parcial da personalidade, tomada de maneira isolada, que pode ser considerado um indicador objetivo de sistemas complexos e subjetivos, que pode derivar sua importância para estudos da personalidade (REY, 2004). 


\section{QUALIDADE DE}

\section{VIDA NO}

TRABALHO E

NAS EMPRESAS 
A Qualidade de vida no trabalho (QVT) é um assunto bastante recorrente nos dias de hoje, dentro e fora das empresas, e poucas vezes, existe um entendimento e uma aplicabilidade de forma eficiente desta proposta. Neste sentido, os entendimentos e as discussões sobre o tema ocorrem em relação a um cuidado de vida e do bem-estar de pessoas e grupos, comunidades e, além disso, aos cuidados de vida do planeta. Em vista disso, se faz necessário esclarecer que as discussões sobre o conceito de qualidade de vida, possibilita escolhas de bem estar e a percepção do que pode ser feito, para ampliar expectativas dos gestores com relação aos funcionários e as atuações da QVT nas empresas (FRANÇA, 2010).

Então, na Década de 1930, como forma de reação contra a Administração Científica de Taylor, surge a Escola das Relações Humanas, e após alguns experimentos psicológicos no rendimento dos trabalhadores ocorreram grandes contribuições, com o intuito de melhorar as relações e os fatores humanos. Logo, o termo QVT surge em 1950, por Eric Trist, para reduzir e melhorar a produtividade e dar melhores condições de vida aos trabalhadores, equilibrando assim a vida dos indivíduos e a organização. (FERREIRA, 2013).

Ainda neste contexto, a qualidade de vida no trabalho (QVT) retrata o grau em que os membros da organização são aptos a satisfazer suas necessidades pessoais, como também na organização. Desta forma, constato que a qualidade de vida no trabalho pode envolver outros fatores que ampliam a significação, tais como: a satisfação com o trabalho executado, as possibilidades de futuro na organização, o reconhecimento pelos resultados alcançados, o salário percebido, os benefícios auferidos, o relacionamento humano dentro da equipe e da organização, e o ambiente psicológico e físico de trabalho, a liberdade de atuar e responsabilidade de tomar decisões e a possibilidade de estar engajado e de participar ativamente na organização, liberdade de decidir, e assim por diante (CHIAVENATO, 2000). 
No entanto, a insatisfação se torna um aspecto importante na relação da vivência, inferida no comportamento nas organizações. No caso dos trabalhadores, de certa forma, executar uma tarefa sem investimento material ou afetivo exige a produção de esforço e de vontade, apenas uma forma de suportar pelo jogo de motivação e do desejo (DEJOURS, 2015).

No entanto, muitos estudos novos estão sendo realizados, podendo fundamentar a escola organizacional e a nova competência de Gestão Avançada em QVT, como, por exemplo, tais elementos:

- a expansão da qualidade de processos e produtos para a qualidade pessoal;

- uma gestão de pessoas, com ênfase em estratégias e participação;

- a imagem corporativa integrada ao endomarketing;

- a descontração, as atividades físicas, o lazer e o desenvolvimento cultural;

- o risco e o desafio no trabalho como fatores de motivação e realização pessoal;

- o desenvolvimento humano e social por meio da educação para a cidadania e,

- por fim, a saúde como espelho das camadas biológicas, psicológicas, social e organizacional.

Estes elementos da Gestão Avançada em QVT "têm a arquitetura da espiral de evolução do conhecimento, fluxos e tarefas do modelo dinâmico de G-QVT" (LIMONGI-FRANÇA, 2010, p.182). Ainda, continuando a ampliar o pensamento da autora citada, entendo que os elementos da Gestão Avançada em QVT (G-QVT) apresentam uma arquitetura espiralizada de evolução do conhecimento e que além disso, noto que a base hermenêutica tende a sustentar valores, tarefas e fluxos que mostra a dinamicidade da G-QVT. 
Desta forma, percebe-se a possibilidade de entendimento que através do gênero conto percebo uma maneira de praticar a ficção, e ser encontrados de forma adequada para exprimir a rapidez com que tudo se altera no mundo real e moderno do trabalho. Além disso, o conto é o ponto fundamental da história, e jamais deixará de ser o conto a narrativa como tal se engendra. Logo, os contos podem ser elementos literários que podem favorecer para a identificação de ações e registros literariamente representativos e singular (MOISÉS, 2012).

Entendo que nos contos existe uma forma narrativa de menor extensão, mas que se torna diferente dos demais gêneros literários para análise do tema, pois a extensão ocorre com características estruturais próprias. Além disso, o conto abarca a totalidade da vida dos personagens, como forma de uma amostragem, como um flagrante ou instantâneo, registrado somente no momento específico (SOARES, 2003).

Em vista disso, o conteúdo temático de um gênero conto, determina uma finalidade do discurso ou o próprio entendimento comunicativo. Desse modo, considero que o conteúdo temático do gênero pode ser modificado, principalmente, pelas escolhas da comunidade em que se envolvem a circulação dos contos, tendo em vista as crenças, os conceitos éticos, a cultura, e as vivências de cada sujeito, visando assumir propósitos moralizantes, ou apenas divertimento para as pessoas envolvidas no contexto de apenas algum divertimento (BAKHTIN, 2010).

Nessa concepção, a ideia de qualidade de vida (QV) pode ser entendida também, de forma bem reduzida, como a união de alguns fatores que possibilitam equilíbrio e bem estar humano, mas compreendido com poucas pesquisas na literatura cientifica quanto ao conceito de QVT.

Os estudos clássicos, como Maslow (1954) e Herzberg (1968), se ocupavam de fatores motivacionais ligados às necessidades humanas, como reflexos de desempenho e na autorrealização do indivíduo. De acordo com os estudiosos, todo ser humano possui necessidades que se sobrepõem umas às outras de forma hierárquica. 
Em 1943, o psicólogo Abraham Maslow divulgou o estudo que enfatizou a importância da compreensão das tais necessidades, fisiológica, segurança, amor e relacionamento, estima e auto realização nas seguintes condições, mostradas na Figura 1.

As necessidades da Pirâmide de Maslow determinam situações presentes nas questões de trabalho, servindo como critérios e indicadores específicos das necessidades humanas. Ainda, as questões fisiológicas, de segurança social, autoestima e a autorrealização podem direcionar as vivências na construção da subjetividade. Para os sujeitos que atuam no contexto do trabalho, as questões da Pirâmide de Maslow permeiam vários caminhos da compreensão e da realização destas questões. Conforme Ferreira (2013), a procura pela melhoria de condições de vida amplia as pesquisas e desperta a curiosidade em entender o que é qualidade de vida no trabalho.

Figura 1. Esquema Clássico de Necessidades.

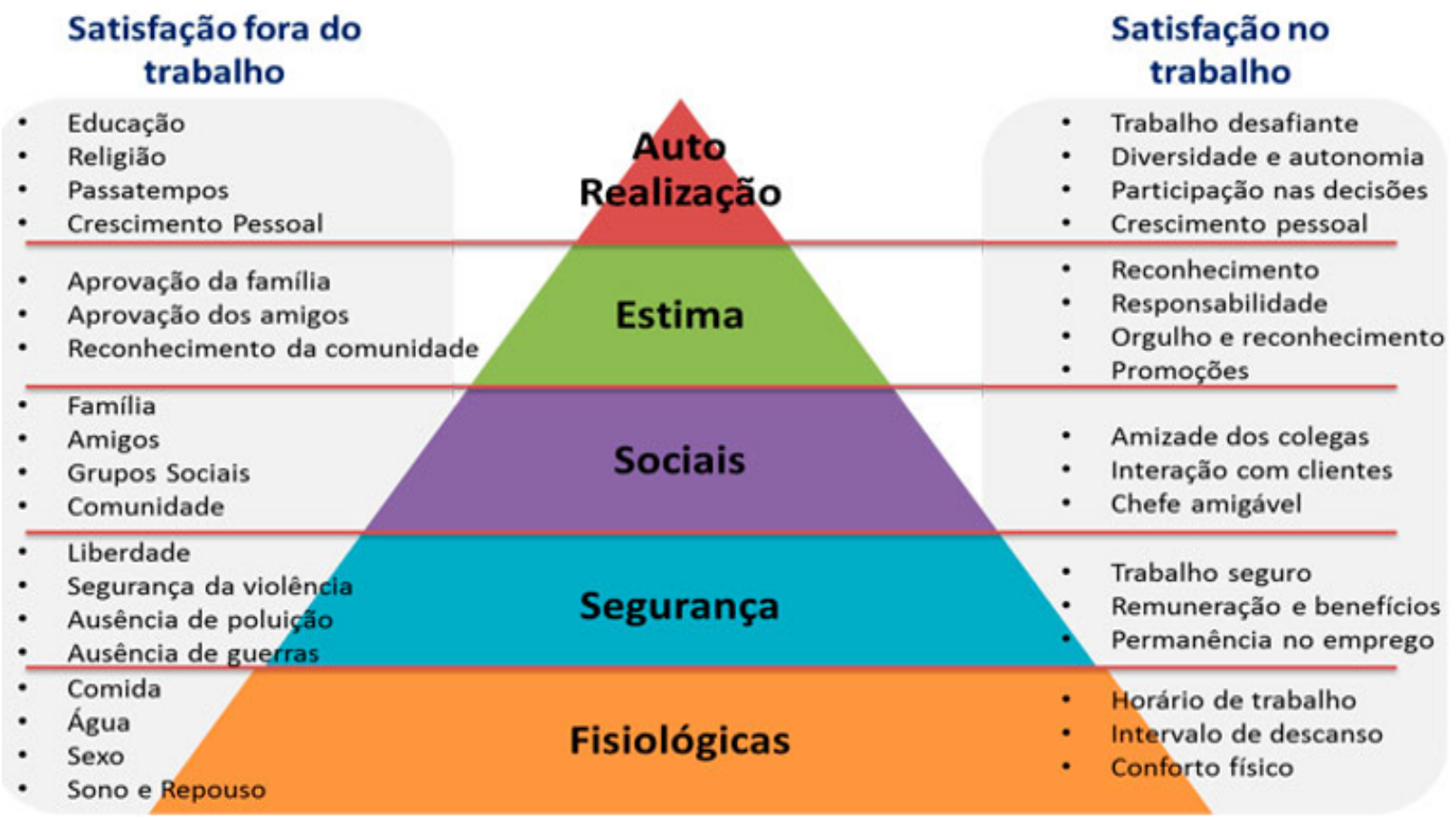

Fonte: Maslow; Herzberg em Fernandes (1996). 
As condições de vida se apresentam no percurso da trajetória do sujeito, que na maioria das vezes, inicia uma reflexão sobre si mesmo e uma (auto) orientação, criando condições e possibilidades para as tomadas de consciência provocadas no processo de favorecimento social (JOSSO, 2004, p. 60).

Com isso, a QVT é o conjunto de ações que a empresa realiza para implantar melhorais e inovações gerenciais, tecnológicas e estruturais, para os sujeitos, no ambiente de trabalho. Ocorre, neste sentido, um novo olhar chamado enfoque biopsicossocial que compreende em três níveis: biológico, psicológico e o social. A partir desta visão compreende a QVT da seguinte forma:

[...] no nível biológico, estão as características inatas ou adquiridas ao longo do tempo. Inclui metabolismo, vulnerabilidades e resistências físicas. No nível psicológico relaciona-se aos processos emocionais, afetivos e de pensamentos, conscientes e inconscientes, que moldam a personalidade e o modo de perceber e se relacionar com as pessoas e o mundo. O nível social envolve os valores, as crenças e a forma de participação do indivíduo em todos os grupos de que faz parte (FERREIRA, 2013, p. 113).

Do mesmo modo que QVT propõe entender que biopsicossocial é um conceito fundamental, também o comportamento nas organizações pode ser bastante imprevisível, pois respeita-se a subjetividade de cada indivíduo no contexto das empresas. 
A TRANSFORMAÇÃO

\section{DO MÉTODO}

EM PROPOSTA

NARRATIVA 
Para a realização desse estudo foi elaborada uma revisão bibliográfica sobre os fatores que afetam a saúde do trabalhador e a qualidade de vida, visando o enfrentamento, as transformações e as mudanças no mundo do trabalho. Para a coleta de dados, utilizei algumas histórias de conteúdos narrativos das seguintes obras:

- "Trabalho e Vida Pessoal”, de Carlos A. Barbosa: "O crime imperfeito", “ Faixa Preta”, “ Dia 22 de Dezembro" e "Festa de Natal”;

- "Tira o Pé da Minha Marmita”, de Regina De L. Baldoni: "Todo mundo em Pânico" e "Chuta Que é Macumba".

Os contos foram selecionados pelas palavras-chave: estresse, comprometimento, vergonha, culpa, a saúde do trabalhador e o enfrentamento no contexto de trabalho. Os demais contos foram excluídos, no estudo da obra, pois não contemplaram pela temática e palavras-chaves propostas.

Uma breve apresentação da obra, nos faz entender os momentos em que a autora constrói elementos que nos remete à realidade atual dos trabalhadores em diversas funções e cargos em diferentes empresas. Apesar do cenário triste, representado através das histórias narradas vivenciadas de forma dramática, tem um lado bem-humorado com que a autora apresenta o mundo do trabalho.

Desta forma, essa temática de estudo se faz necessária em discussões teóricas relacionadas às práticas do cotidiano de trabalho nas organizações. E nesse sentido, é possível entender como se dá a proteção da subjetividade do indivíduo e como estão construídas as narrativas sob a perspectiva literária em contos. A pesquisa qualitativa preocupa-se, portanto, com aspectos da realidade que não podem ser quantificados, centrando-se na compreensão e explicação da dinâmica das relações sociais (MINAYO, 2001). 
Para a realização da Análise Qualitativa de Dados (BARDIN, 2010), foi utilizada a análise de conteúdo, sendo o conjunto de técnicas de análise de comunicação que tem por objetivo obter a descrição do conteúdo das mensagens, a produção e a recepção dessas mensagens. Desta forma, os procedimentos da análise de conteúdo possibilitaram delinear as seguintes categorias: relacionamentos humanos, percepções da qualidade de vida, saúde do trabalhador e comprometimento com a empresa.

Para Josso (2004), os contextos em que se vivenciam as experiências são contextos de interações e transições, que entre sujeitos, ocorrem contatos nos mesmos ambientes, estabelecendo conexão com contextos referenciais socioculturais formalizados e, portanto, mais gerais. Nestes espaços, o sujeito dentro pode realizar um enquadramento interpretativo, a fim de ampliar suas considerações.

Portanto, as técnicas de coleta de dados foram utilizadas com os cinco contos selecionados e não possuem formato de perguntas, mas interpretações que considerem o entendimento e definição do problema e dos objetivos da pesquisa, tais como parte dos dados a serem coletados, sem interferências do pesquisador, que deverá apenas destacar as características encontradas nos contos (GIL, 2002). 


\section{REFLEXÕES NAS}

PESPECTIVAS

DAS NARRATIVAS

NOS CONTOS 
Os contos apresentam descrições que, assim, tornam viáveis as análises de conteúdo por categorias. Desta forma, é importante ressaltar que pela análise de conteúdo foi possível entender o que está por trás do conteúdo manifesto, ou seja, o que está implícito do que foi manifestado nos contos.

A partir desse procedimento, cheguei às seguintes categorias: relacionamentos humanos, saúde do trabalhador e comprometimentos com a empresa, as percepções da qualidade de vida e, por fim, os aspectos psicológicos, físicos e relações sociais que tendem aparecer nos contos. A escolha dos nomes das categorias deu-se através dos objetivos do trabalho e do entendimento obtido no processo de leitura do que mais apareceu nos contos.

A análise de conteúdo é um conjunto de técnicas de análise de comunicação, assim sendo, é destacada neste campo a importância da semântica para o desenvolvimento do método. (BARDIN, 2010). Desta forma, a questão semântica pode ser utilizada na análise dos contos no contexto do trabalho como será apresentada no decorrer das categorias.

No quadro 1, são descritas as numerações, os títulos dos contos e das obras, como exemplos extraídos do corpus e posteriormente será explicado qualitativamente os contos analisados.

Quadro 1: contos e obras com descrições parciais.

\begin{tabular}{|c|c|c|}
\hline NUMERAÇÃO & CONTOS & OBRAS \\
\hline 1 & "Todo mundo em pânico". & Tira o Pé da Minha Marmita \\
\hline 2 & "Chuta que é macumba". & Tira o Pé da Minha Marmita \\
\hline 3 & "Crime imperfeito". & Trabalho e Vida Pessoal \\
\hline 4 & "Faixa preta". & Trabalho e Vida Pessoal \\
\hline 5 & $\begin{array}{r}\text { "Dia 22 de dezembro. } \\
\text { Festa de Natal!" }\end{array}$ & Trabalho e Vida Pessoal \\
\hline
\end{tabular}

Fonte: Autora. 
A descrição das obras citadas, no quadro, aponta os contextos de trabaIhos, crenças, festividade, stress, entre outras, como temáticas que podem ser analisadas com a relação das personagens aos seus trabalhos e demandas nas instituições. 


\section{CONTEXTUALIZAÇÃO}

DOS CONTOS NO

CONTEXTO DO

TRABALHO 
O contexto de trabalho no conto (1) "Todo mundo em pânico", se dá em uma empresa de autopeças, com trabalhadores de vendas internas. A empresa com movimentos de clientes bastante acelerada e triplicando a cada ano. A contratação de funcionários não ocorre e os funcionários, devido ao aumento de trabalho, não conseguem dar conta e acabam por apresentar inúmeros problemas de saúde.

Já no conto (2) "Chuta que é macumba" o contexto organizacional se dá em uma empresa, cuja consultora de vendas se tornara um exemplo de eficiência no trabalho pela assiduidade e responsabilidade com horários de chegada, atendimentos aos clientes, sendo indicada para muitos treinamentos técnicos para aperfeiçoar suas habilidades para o ambiente de trabalho. Em um dia de trabalho, um telefonema familiar urgente fez a funcionária alterar o seu contexto de trabalho, causando novas concepções e conceitos na empresa e as habilidades de humanização na visão da organização.

O conto (3) intitulado " Crime Perfeito", narra a história de uma empresa que cria um programa de desenvolvimento gerencial, com o objetivo de qualificar um grupo de técnicos para atuarem em seis novas áreas que seriam criadas a partir de reestruturação da empresa. Neste contexto, o programa da empresa elaborava critérios que selecionavam os escolhidos como: assiduidade, prontidão, responsabilidade e desempenho, todos beirando trinta (30) anos de idade, com fluência em inglês, estrutura familiar estável e ainda outros requisitos não apontados no conto. No entanto, neste conto percebemos um diferencial no contexto, pois o processo de imersão se dá em uma cidade do interior, entre trabalhadores, além da proposta de estágio por dois anos na matriz para os funcionários selecionados no momento do treinamento em desenvolvimento gerencial.

No conto (4), "Faixa preta” é a história de um profissional da aviação, comandante, que durante a atuação intensa na profissão, percebeu que tudo 
finalizou muito rápido e pouco viveu a vida, finalizando a carreira com ampla medicação faixa preta.

E por fim, o conto (5) finaliza com uma narrativa natalina, intitulado " Dia 22 de Dezembro... Festa de Natal!" que retrata a festa da empresa e seus trabaIhadores, deixando para trás os momentos de tensão, por momentos festivos e que todos podem ser unidos em torno de só um objetivo, a festa da empresa. Os contos serão analisados e exemplificados por categorias extraídos do corpus em análise.

Nesta visão do contexto histórico das empresas narradas, ocorre momentos de reflexão com os fatos da nossa atualidade, mediante enganos e desenganos no mundo do trabalho, os trabalhadores desconhecem os acontecimentos e, por isso, a necessidade de comtemplar com contos narrativos. 


\section{REFLEXÕES E}

\section{CONSIDERAÇÕES}

\section{MEDIANTE}

CATEGORIZAÇÃO 
A análise dos contos se dá pela categorização, sendo esta uma operação que classifica os elementos constitutivos de um conjunto, por diferenciação e por classificação de elementos em comum com os outros. Desta forma, a categorização é um processo estruturalista, constituído em duas etapas: o inventário (isola os elementos) e a classificação dos elementos.

Desta forma, as categorias são rubricas ou classes, reunindo grupos ou temas, sendo analisados, também, pelos critérios semânticos, sintáticos léxicos ou a forma expressiva da linguagem (BARDIN, 2010). Nesta categoria de aspectos semânticos destacam-se questões relativas aos relacionamentos humanos dos quais podemos observar na primeira categoria de análise.

\section{RELACIONAMENTOS E VIVÊNCIAS NO MUNDO DO TRABALHO}

Nos contos analisados, a percepção entre as atuações no campo do trabaIho, construída entre os personagens, a questão dos relacionamentos humanos pode ser uma grande fonte de estresse. A política de desconfiança entre os colegas de equipe nas organizações, torna o dia-a-dia um grande desafio de estabelecer um comportamento satisfatório no trabalho:

"....a empresa criou um programa de desenvolvimento gerencial, com objetivos de qualificação (...) até que percebi que em uma das atividades “ vivenciais", que um integrante do grupo parecia apático e desmotivado, chamou minha atenção a falta de entusiasmo (...) me dei conta que nunca o vi sorrindo (...) e uma colega falou: só porque ele é antipático não significa que ele não está qualificado. "(3)

"O gerente de controladoria, funcionário antigo, próximo dos 60 anos de idade, gordinho, barrigudinho, (...) mas tímido "fechadão". Sorria pouco o gerente de controladoria, que também não tinha um índice de popularidade dos mais expressivos junto aos seus trabalhadores e demais funcionários da empresa." (5) 
De acordo com as descrições acima, percebo que o comportamento dos personagens descrito não satisfaz a equipe e nem a gestão, o que pode ser rotulado a uma determinada percepção que transforma o ambiente de trabalho. Um fator importante analisado é a desmotivação que parece desagradar a equipe de trabalho. As empresas estabelecem critérios de mudanças e os funcionários passam a desempenharas funções com treinamentos e promoções, com o objetivo de intensificar a motivação e a satisfação pelas funções e cargos que exercem na empresa. No conto 5, por exemplo, o fator idade aparece com o estereótipo do trabalhador mais velho, como antigo e de pouca popularidade. Com isso, a narratividade nos contos mostra, as formas e a percepção dos relacionamentos humanos que estabelecem alguns fatores, tais como estresse ocupacional ou forma particular de desempenho, visando, também, um possível acúmulo de trabalho (BORGES; MOURÃO, 2013).

O baixo nível de estresse ocupacional tem sido analisado nas organizações como fator fundamental para o bom relacionamento entre os funcionários, sendo que o desgaste no trabalho ou o excesso também pode levar às reações de desgastes psicológicos, físicos e comportamentais (SPECTOR, 2014). Considero que as reações psicológicas nos contos envolvem várias demandas emocionais como ansiedade, tristeza, frustração e outras, quando as atividades não correspondem ao sucesso satisfatório na organização.

“- Parece que teve uma crise de pânico. Se isto for confirmado, ele pode sair do programa”. (3)

"Sueli entrou em um grau de ansiedade tão grande que um dia foi levada às pressas a um pronto-socorro, pois seu corpo todo travou e começou a tremer sem parar. No hospital foi diagnosticada quase uma parada cardíaca". (1)

As reações físicas também podem diversificar, causando afastamento do trabalho e inúmeras dificuldades comportamentais, pelos fatores de uso de me- 
dicamentos, tabaco, drogas, e/ ou possíveis acidentes de trabalho.

"Pouco tempo depois, devido ao desconforto, a equipe começou a brigar entre si e descarregar toda a insatisfação e frustração uns nos outros." (1)

“(...) As faixas são as estampas nas caixas de remédios, que sou obrigado a tomar todos os dias." (4)

Nos contos analisados, as reações físicas durante o trabalho as empresas, precisam ser investigadas e tratadas com programas de prevenção da saúde do trabalhador, com treinamentos, melhorias das atividades em equipes, priorizando os relacionamentos humanos entre os trabalhadores, ampliando debates sobre a importância do profissional no contexto da organização, a valorização e o reconhecimento dos funcionários no ambiente de trabalho, o que não verificamos descritos nos contos. Um fator imaginário das organizações refere-se ao tempo que as empresas lutam para aumentar constantemente a produtividade dos funcionários e a dedicação intensa à organização (SIQUEIRA, 2009).

Além do ritmo acelerado de trabalho e o acúmulo de funções, as empresas propõem treinamentos e troca de funções que favorecem a melhoria no currículo aos funcionários. Conforme observa-se nos fragmentos dos contos (1) e (2):

"Todos trabalham como vendedores internos em uma empresa de autopeças há mais de três anos. O ritmo de trabalho sempre foi bastante acelerado e o movimento na empresa triplicou (...) além da empresa decidir fazer programas de treinamento focados em atendimento ao cliente, conhecimentos técnicos e reuniões motivacionais.

“(...) Paula, administradora de empresa, na época de sua contratação, para estar apta a atender os clientes da empresa em questão, passou por intenso treinamento técnico sobre os materiais que iria oferecer. (...) Tudo corria bem para a empresa, embora Paula estivesse sem vida pessoal, pois todo o seu tempo estava preenchido com as diversas atividades que ela havia se comprometido a desenvolver; o atendimento aos clientes, reuniões e seus cursos. (2) 
O discurso que perpassa nos dois contos, as questões de melhorias no currículo dos funcionários denotam a preocupação das organizações em qualificar a equipe e ampliar suas competências, na tentativa de motivação das empresas valorizarem o conhecimento, de cada funcionário e / ou trabalhador, com treinamentos que desenvolvam, com habilidade, os propósitos da organização.

No entanto, o conto (2) evidencia que a organização valoriza a função e as atividades prestadas pelo funcionário, na intensa busca por mais qualificação e treinamento, para ampliar as condições de trabalho, como, também, comprometimento com as ações e atividades na empresa. No entanto, a qualidade de vida está afetada neste contexto, por não existir tempo para qualquer momento familiar e pessoal, tempo amplo de trabalho e comprometimento com as atividades da empresa, justificando o tempo preenchido pelo trabalhador.

Contudo, nos dois contos, a empresa poderia realizar treinamentos para seus funcionários de forma diferenciada, contribuindo para uma melhor QVT. Com isso, a relação humana entre as equipes ou de forma individual, pode objetivar diferente atuações de desenvolvimento nas organizações e poucos questionamentos na satisfação do trabalho (SPECTOR, 2014). Por entendimento das relações de satisfação do trabalho, analisarei na próxima categoria os itens, apontando fatores de saúde do trabalhador e o comprometimento do funcionário no contexto da empresa.

\section{SAÚDE DO TRABALHADOR E O COMPROMETIMENTO COM A EMPRESA}

O processo de trabalho tem sido um dos aspectos fundamentais das pesquisas no campo de saúde do trabalhador, considerando os fatores determinantes das condições de desgaste e adoecimento, identificando os aspectos psicossociais e culturais. Nas últimas décadas, o cotidiano do trabalhador, o esforço de atender aos novos papéis e o cuidado com a saúde mental, têm sido abandonados pelas políticas públicas (MOSER; KERBING, 2006). 
Com isso, o descaso e o abandono com o corpo de quem trabalha, produz novas necessidades básicas e um maior cuidado com os valores da vida e a saúde mental do trabalhador. Observe nos exemplos de contos como a saúde do trabalhador se representa.

“(...) com o tempo as pessoas começaram a ter problemas de saúde. Cada um que saía para uma consulta, ou até mesmo para o pronto-socorro, acabava sobrecarregando o restante da equipe. Carlos, que costumava ser um rapaz animado e simpático, estava se tornando apático e desanimado. Procurou um psiquiatra e passou a tomar medicamentos psicotrópicos. André (...) crises de ansiedade, que um dia (...) teve uma crise que o corpo travou e começou a tremer sem parar (...), Catarina (...) chorava várias vezes por dia e apresentou fortes cólicas de rins (...)" (1).

“(...) "ouvi um colega comentar que Adriano estava na enfermaria com dores no tórax, não participaria da reunião. (...) Acho que ele está estressado, nervoso, parece uma panela de pressão... Na verdade, não identifiquei nada físico...dei um calmante fraquinho e deixei-o aí para relaxar" (3).

No corpus analisado nos contos, a saúde mental dos trabalhadores sofre com relação à pressão das organizações que se utilizam de metas, prazos e treinamentos excessivos com seus trabalhadores. Os trabalhadores apresentam sintomas de sofrimento invisível que ultrapassa o individual, afetando o desempenho produtivo da equipe pela fadiga, que faz o aparelho mental perder sua versatilidade; o sistema frustração- agressividade reativa; e a organização do trabalho, como correia que transmite a vontade externa, se opondo aos investimentos pulsionais e as sublimações (DEJOURS, 2015).

Desta forma, verifiquei também nos contos que o comprometimento dos funcionários, corresponde ao pertencimento na relação ao trabalho e a equipe, ou seja, o adoecimento de um colega; pode-se fazer a inferência a partir das comunicações entre setores e os demais da equipe representada no conto (3), tornando, assim, em um momento de aflição às pessoas da organização. Observe no fragmento do conto (2), alguns aspectos de comprometimento. 
“(...) a empresa estava muito satisfeita com seu trabalho. (...) em um dia de reunião, entre uma ligação e outra, recebeu uma chamada urgente de sua mãe, que, desesperada, informou-lhe que seu pai, passando muito mal, estava sendo levado para o hospital. Paula, mais que depressa, correu em direção ao estacionamento da empresa. (...) o pai havia sofrido um AVC hemorrágico e precisava de cirurgia. (...) Diante da situação, Paula ficou três dias sem comparecer a empresa, com consentimento de seus superiores. (...) No dia seguinte, sua gerente a chamou para uma conversa particular.

Neste sentido, questiono ainda de como pode ser visto na empresa, o comprometimento do trabalhador:

(...)" essa situação que seu pai está atravessando é muito incerta e instável. Isso torna praticamente impossível que você dê continuidade as suas atividades aqui na empresa. Devido ao fato de ter se ausentado por três dias, a diretoria e eu achamos que faltou comprometimento de sua parte para com a empresa, então decidimos dispensá-la. (2)

O termo comprometimento analisado neste conto, pode ser representado por um fator que indica pouca responsabilidade por parte da funcionária nas atividades assumidas, e que exige ainda mais responsabilidade desde o momento da contratação. Dessa forma cabe ressaltar que ocorre no conto, como justificativa "os dias de ausência", pelos quais os gestores apontam a falta de comprometimento no processo de demissão. O processo dado como feedback, em que o funcionário assume muitos compromissos na empresa, conforme o fragmento:

"você havia se comprometido a desenvolver: o atendimento aos clientes, reuniões e seus cursos."(2)

Neste caso, no conto (2), além das condições de eficiência assumidas pela funcionária, vale frisar que o excesso de compromisso ocorre para melhorar a confiança e o desempenho com relação aos gestores. No entanto, acaba por prejudicar e relativizar a relação que conclui no processo demissional, ou seja, não 
foi considerada a situação de adoecimento do familiar e os aspectos psicológicos e sociais vividos por esta funcionária. Desse modo, a demissão de funcionários ocorre, às vezes, de surpresa, sem a possibilidade de reverter a situação, após a decisão efetiva, junto do departamento de gestão de pessoas (SPECTOR, 2013).

Portanto, a saúde do trabalhador deve ser pensada de forma efetiva, para que o trabalhador demitido e a equipe que permanece trabalhando na empresa, possam continuar o processo atenuando sentimentos de medo, raiva, injustiça, ou que os faça se sentirem conivente com o ocorrido (SERRA, 2010).

Outro conceito de comprometimento analisado nos contos se dá com relação a processo de vivência e vínculo que o indivíduo tem a partir do trabalho. Observe no fragmento do conto (4) outro aspecto de comprometimento do indivíduo no trabalho:

"Hoje vivo envolvido com o passado que vivi e vibrava com os voos que fazia. (...)Hoje, aposentado, sinto saudade do ir e vir. (...)No aeroporto, todos olham com admiração os tripulantes. Sempre bem arrumados, penteados, (...). Os anos voaram na velocidade dos aviões. Esqueci que ia envelhecer e que teria que dar adeus àquilo tudo que ainda me envolvia. Se você não se preparou e no final das contas saiu ganhando faixas pretas, que ótimo, saiu no lucro. As faixas pretas são as estampadas nas caixas de remédios, que sou obrigado a tomar todos os dias. A dinâmica de voo, a rapidez do raciocínio e o não -parar fizeram com a minha vida fosse elétrica, como a energia que passa nos cabos de alta tensão."(4)

Observei o conto que o indivíduo comprometido e engajado com o trabalho sente prazer em trabalhar na organização, acredita nos valores e nos objetivos organizacionais. No entanto, as relações sociais são positivas, por isso exerce esforço em benefício da empresa, a fim de contribuir para o bem-estar da organização. Com isso, a ligação afetiva, crença e aceitação dos valores da organização, são identificadas com o sentimento de desligamento no processo de final de carreira (BORGES; MOURÃO, 2013). 
Ao analisar o conto (4), é notório que o funcionário aprecia falar do seu trabalho, sentindo orgulho na sua atuação e, também, no caminho percorrido na profissão durante muitos anos de forma positiva. Avaliando, ainda gostar do que faz, como uma autoavaliação, autoconhecimento, elevando a auto-estima.ao elencar as virtudes encontradas nas questões da subjetividade de enfrentamento do real. Dessa maneira, o elitismo da aeronáutica, os pilotos são considerados "os cavaleiros do céu", além disso, a valorização do corpo e do espírito pela situação de trabalho é exemplar da síntese trabalho intelectual-trabalho-manual (DEJOURS, 2015)

Constatei neste conto, que o mundo do sujeito se restringe em torno dos medicamentos, isto é a fonte de uma explicação para a falta de preparação do futuro do trabalhador nas organizações. Sem dúvida, a questão do tratamento com psicofármacos é uma demonstração de que, para alguns trabalhadores, o trabaIho está intimamente ligado à questão da identidade. E nesta falta de preparação do futuro do profissional, o que poderia ser natural pode causar o adoecimento do sujeito nesta transição.

Por outro lado, observei que existe uma necessidade de elaborar novas propostas para que na gestão das empresas utilizem modos de trabalhar, abordando, por exemplo, o estudo da aposentadoria, tanto para aqueles que desejam continuar no mercado de trabalho, como para os que vislumbram a sua saída, ajudando no processo final do mundo do trabalho organizacional. Dessa forma, a organização é a causa de uma fragilidade somática e a adequação das necessidades de sua estrutura mental (DEJOURS, 2015).

Em relação ao que foi exposto, entendi que a qualidade de vida no trabalho requer um processo de análise no mundo e do trabalho e das organizações, que propõem pensar em novas propostas para uma gestão colaborativa, e com várias situações do contexto do trabalho. Isto será desenvolvido na próxima categoria da QVT. 


\section{QUALIDADE DE VIDA NO TRABALHO (QVT) E AS NARRATIVAS}

A qualidade de vida no trabalho tem sido um tema com bastante relevância na questão de produtividade das pessoas e os resultados obtidos nas organizações. Com isso, a procura pela melhoria de condições de vida amplia as pesquisas e desperta a curiosidade em entender o que é qualidade de vida no trabalho (FERREIRA, 2013).

Para Josso (2004), existe o decurso da situação de narrar e contar através de histórias um mundo em que o sujeito necessita de conhecimentos de si, para poder decidir os elementos que podem ser narrados. Além disso, através dos contos podemos perceber as sutilezas nas construções narrativas, os sujeitos e seus respectivos locais de trabalho. Desta forma, há dificuldade em estabelecer momentos de controle emocional para abordar suas histórias de vida, passagem de fatos que proporcionaram vivencias e experiências como processo de aprendizagem.

Nos contos analisados, evidencio elementos que identificam a qualidade de vida como um assunto pouco sinalizado ou identificado nas narrativas pelos funcionários e pelas organizações. A qualidade de vida implica em criar, manter e melhorar o ambiente de trabalho seja nas condições físicas, psicológicas e sociais, resultando em um ambiente agradável e amigável melhorando a qualidade de vida das pessoas nas organizações.

Observe nos fragmentos retirados dos contos (1) e (3) como exemplos:

"Todos esses treinamentos eram dados fora do horário de expediente, forçando os funcionários a chegar uma hora mais cedo pelo menos três vezes por semana e saírem duas horas mais tarde, dependendo do assunto a ser tratado." (1)

"O que uma pessoa precisa ter para ser um grande executivo? A empresa criou um programa de desenvolvimento gerencial com objetivo de qualificar um grupo de técnicos para atuarem em seis novas áreas 
que seriam criadas partir da reestruturação. (...) No programa incluía-se: imersão em uma cidade do interior para aprimorar o inglês, benchmark para ter modelos, entrevistas e reuniões com diretores e presidentes, várias e várias atividades, dinâmicas/vivencias para liderança, proatividade e o mais interessante: estágio na matriz com duração de dois anos."(3)

Nos contos (1) e (3), os vários treinamentos são oferecidos para os funcionários, exigindo um resultado que atenda a melhoria da demanda técnica de todos, sem excluir ou priorizar setores. Em alguns casos pode ocorrer critérios de seleção de alguns funcionários como bonificação no trabalho.

O tempo de treinamento destes funcionários ocorrem dentro e fora do horário de trabalho, com tempo estabelecido pela gestão para iniciar e finalizar as atividades, e por vezes, pode ocasionar um excesso de carga horária de trabalho, consequentemente, refletindo na qualidade de vida desse trabalhador.

Desta forma, o trabalho denota um maior afastamento do contexto familiar e da vida social, o que, muitas vezes, pode-se considerar um fator importante, para um mau funcionamento psíquico do sujeito, levando este a possíveis sintomas de transtornos psicológicos. Com isso, entende-se que pode existir no mundo do trabalho a "vivência depressiva, que condensa de algum modo os sentimentos de indignidade, de inutilidade, de desqualificação, ampliando muitos outros sentimentos do trabalhador" (DEJOURS, 2015, p.62).

As empresas descritas nos contos criam situações que prioritariamente visam desenvolver as habilidades profissionais dos funcionários, mas que não levam em consideração algumas questões pessoais de infraestrutura familiar dos seus trabalhadores. No entanto, a qualidade de vida no trabalho implica, também, em proporcionar e ampliar esta comunicação dos funcionários com a gestão, visto que ocorram novas formas de realizar os treinamentos com propostas viáveis aos contextos sociais dos funcionários (LIMONGI-FRANÇA, 2010). 
Outro aspecto importante, verificado no conto (3) refere-se ao programa de imersão em uma cidade do interior e o estágio na matriz com duração de dois anos, um possível afastamento familiar. Esse conto destaca cada vez mais a importância do crescimento pessoal e profissional, suprindo as necessidades das empresas e dos trabalhadores cada vez mais competitivos e estressados no mercado de trabalho. No entanto, os efeitos da aceleração das mudanças obrigam as pessoas que atinjam um nível inevitável de "estresse fisiológico" - uma forma de alerta, refletindo em vários ângulos da vida do indivíduo (SANT'ANNA; KILIMNIK, 2011, p.185).

“ - Nosso relacionamento está bastante balançado. Vem me aporrinhando por causa da viagem, mas não quer que eu vá de jeito nenhum, mesmo sabendo que é para meu crescimento, que tudo pode melhorar. Não é falta de promessa. Já disse que me casarei assim que voltar, e ainda ela poderá passar um período comigo lá fora. (...) ela tinha ligado para o David Rachel (Diretor-Geral) para falar um monte de abobrinha. Disse que eu não merecia esta viagem. Só pra vir para cá foi um sufoco. (3)

Com isso, em primeiro lugar notei que não existe um padrão de qualidade de vida que possa satisfazer a todos, ou seja, cada indivíduo tem sua subjetividade e necessidades diferentes, tanto quanto aos aspectos familiares, sociais e culturais. Assim, os profissionais de Gestão de Pessoas necessitam valorizar a qualidade de vida no trabalho com práticas desenvolvidas pelas empresas, com o intuito de promover e assegurar o bem estar do funcionário com ações que envolvam situações de desenvolvimento de realização pessoal e de trabalho (OLIVEIRA; LIMONGI-FRANÇA, 2005).

Contudo, no conto (5) observei um diferencial de QVT determinado como compensação na "Festa de Natal na empresa". Vale destacar no seguinte exemplo:

“ (...) Todo ano era realizada festa de Natal para seus trabalhadores, que traziam as famílias. Tudo era organizado para uma farta distribuição de 
comes e bebes e presentes para a criançada, quase sempre entregues pelos membros da comissão organizadora da festa. Todos gostavam muito, principalmente a criançada (...). Surgiu a ideia da comissão de contratar um Papai Noel nas festas! (...) . (5)

Neste conto analisado, percebi que em algumas empresas, a qualidade de vida está associada à festividade proporcionada no final de ano, como um fator de reconhecimento e de desempenho profissional, favorecendo a integração social entre membros da organização e ampliando as relações entre familiares e a empresa. Nos contos evicenciei a relevância do trabalho na vida do trabalhador, por sua vez servindo como equilíbrio para o contexto familiar e profissional e possibilitando um momento agradável, satisfatório, sedutor e acolhedor entre os familiares, os funcionários na organização.

Com isso, o investimento em QVT é fator importante para melhorar o desenvolvimento e sucesso de uma organização, sendo necessário que os administradores da empresa, tenham consciência das necessidades e a satisfação dos seus trabalhadores (RIBEIRO; SANTANA, 2015).

\section{OS ASPECTOS PSICOLÓGICOS, FÍSICOS E AS RELAÇÕES SOCIAIS}

O ser humano é um complexo biopsicossocial com potencialidades biológicas, psicológicas e sociais que constituem as condições de vida. Nessa visão, as pessoas podem sofrer com mudanças importantes alterando sua qualidade de vida. Mesmo que não haja uma definição precisa para o conceito de Qualidade de vida, é fundamental entender os aspectos da subjetividade, da multidimensionalidade e a dimensão positiva (LIMONGI- FRANÇA, 2010).

Nos aspectos psicológicos, constato nos contos sentimentos positivos dos trabalhadores em relação "ao seu fazer" na organização, tanto em relação ao trabalho diário, como também em momentos onde o posicionamento do valor do humano fica muito evidente. Outro ponto, observei também os processos afeti- 
vos, emocionais e de raciocínio, conscientes ou inconscientes, que constituem a personalidade de cada pessoa e o modo como se posiciona diante das situações sociais. No entanto, no conto (3) temos o exemplo que pode expressar o trabalho como satisfatório a partir da subjetividade de cada sujeito:

"No aeroporto, todos olham com admiração os tripulantes. Sempre bem arrumados, cabelos aparados e sapatos sempre brilhantes. As companhias são sempre agradáveis, lindas mulheres! Bonitas, inteligentes e dinâmicas. (3)

Papai Noel, diz o gerente de controladoria: Gente! Quando vi aquelas carinhas todas olhando para mim e um garotinho que pulava de alegria, não deu para segurar a emoção! Foi forte demais! Eu era naquele momento o sonho do ano inteiro de uma criança! (5)

Nos contos a valorização dos papéis exercidos pelos funcionários, tanto no momento do trabalho, como na forma festiva de final de ano, fica evidente a questão positiva e valorativa pelas falas dos trabalhadores, fortalecendo um vínculo de fantasia, da emoção e da supervalorização do humano naquele momento em especial.

Certamente que um grande aliado da QVT é adequar programas organizacionais modernos, como tempo livre que trazem um maior ócio criativo, aumento a integração das pessoas por meio de informações e de espíritos cooperativo, podem ser alguns objetivos típicos para a área organizacional de empresas-cidadãs (LIMONGI-FRANÇA, 2010)

No entanto, a falta de cuidado com a saúde mental e física, por sua vez, foram evidenciados nos contos, ocorrem pelos aspectos de dores, fadiga, desistência e desânimo. Da mesma forma, a dependência de medicação ou de tratamentos, isto é, formas de atenuar os sintomas do mundo trabalho. Conforme foi possível identificar nos contos, o modo como a pressão estipulada nos cursos ofertados pelo mundo do trabalho, podem afetar os trabalhadores: 
- Catarina chorava várias vezes por dia e apresentava fortes cólicas de rins.... Carlos, que costumava ser um rapaz muito animado e simpático, estava se tornando apático e desanimado... (1)

- Alguns consideram várias faixas, outros continuam nas faixas vermeIhas.... Hoje eu sou faixa preta. (4)

No conto observei a evidência em que o desânimo é um fator importante para desempenho do funcionário no trabalho, por sua vez, a medicalização predomina nas relações em que o trabalhador atua na empresa. Ou seja, embora os funcionários apresentem sintomas, parece que ocorre um mecanismo de defesa e de negação ao relacionar várias funções no contexto do trabalho, em que sofram maiores pressões, contribuindo para o adoecimento no contexto e a inexistente situação de valorização da QVT. No entanto, para Dejours (2015, p.157) "basta diminuir a pressão organizacional para fazer desaparecer toda a manifestação do sofrimento".

E por fim, vale apontar que as relações sociais são fatores fundamentais nas relações familiares, grupos e suporte social do trabalho, representado nos seguintes fragmentos:

"Meia hora depois, devidamente instruído (o trabalhador) pela comissão organizadora sobre como deveria compor o personagem, eis que entra o Papai Noel no imenso salão do refeitório, onde estavam as centenas de crianças em volta das mesas arrumadas com capricho, muito bonitas com a decoração de motivos natalinos. entra o papai Noel, ...e de repente solta um forte "oh!oh!oh!"'( 5)

Neste fragmento, a relação entre as pessoas da organização no contexto familiar promove um ambiente participativo, festivo e saudável entre os trabalhadores, pois o grande desafio é possibilitar um ambiente oportuno para criatividade, sensações afetivas e de bem-estar entre os diferentes programas da gestão. 


\section{PROFISSAO DE FATOR NOTÁVEL DO TRABALHO: O PROFESSOR}


Ao estabelecer momentos de reflexão sobre as demais profissões, pensamos sobre o trabalho do professor, como significativa retomada na formação e escolhas de cada um dos contos narrados. Ao processo de entendimento nas formações profissionais, frequentamos, de forma privilegiada, uma escola durante um período em nossas vidas, com histórias escolares e as dificuldades de formação que se tornam histórias de vida, vivências de formação.

A reflexão desta proposta de texto narrativo, também nos favorece a pensar em todos os profissionais formados pela e através da escola, em diferentes situações que representa o homem nos diferentes contextos sociais. Deste modo, valorizamos também as profissões e profissionais no mundo do trabalho, com a face do marceneiro, do soldador, do aviador, do administrador, do médico, entre outras, como uma ideia de formação de processo final, e de desenvolvimento reconhecido pelo mercado de trabalho.

Mas e a origem das profissões? Quem forma o profissional? Com quais valores os professores se constituem no processo educativo e simbolizariam através da construção das narrativas de vivências nos contos na obra? Dentro das escolas, dos conteúdos transmitidos, entendidos que pela época escolar dos sujeitos narrados, as suas histórias mostram que existiu contextos educativos, que reorganizavam e planejavam o futuro profissional.

Para Codo (2006), a primeira lição que um profissional do mundo do trabalho aprende é perguntar pelo produto, com vínculo pelo passado e o futuro. $\mathrm{O}$ produto do trabalho é o trabalho que o representa e através do produto, comparece perante os outros homens materializado na sociedade.

Nesta trajetória é que o papel do professor existe na produção histórica do sujeito. Em um plano abstrato, o professor tem representação simbólica de desejo em todas as escolhas das profissões, mas é importante reconhecer para que os outros se reconheçam na construção nesta caminhada (CODO, 2006, p.46). 
Logo, o mundo do trabalho no contexto histórico brasileiro implica o enfrentamento das mudanças ocorridas e das implicações que as organizações públicas e privadas reconhecem na valorização dos professores, tais como melhores salários, condições de trabalho, tempo de planejamento das ações e reconhecimento social e histórico na construção das profissões (FREITAS, 2013).

No entanto, o planejamento de um trabalho educativo requer mais que um lugar e um papel social, requer valorização profissional e formação, e por isso, entendo que o saber-fazer está nas mãos do professor, como condição principal de sua profissão e nas propostas de atividades de trabalho (CODO, 2006).

Enfim, o professor é um profissional que possibilita mudanças sociais, através das suas ações, práticas e vivências, estabelecendo desafios de aprendizado e de formação para novas gerações de profissionais e educadores, com maior criticidade e autonomia nas escolhas pelo trajeto de profissionalização. 


\section{REFLEXÕES}

\section{SOBRE}

\section{DEMANDAS}

NA ATUALIDADE 
Neste estudo realizado com contos selecionados, compreendi a importância de reconhecer e debater os conceitos sobre a Saúde do Trabalhador e a Qualidade de Vida no Trabalho. Isto tudo integra os discursos nos textos e a partir da análise de conteúdo que compõem os contos literários das referidas obras.

Ficou caracterizado que os contos são formas de manifestação de discursos narrados e vivenciados pelos trabalhadores que, por vezes, passam despercebidos como processo de aprendizagem, afigurando-se como acontecimentos, vivências, percepções, reflexões, sentimentos e lembranças, algumas agradáveis e outras nem tanto. Nas relações destas histórias com o mundo do trabalho, se faz perceber e valorizar as situações humanas e a subjetividade que consolidam aos trabalhadores por horas e horas no contexto da organização, trabalhando e produzindo junto, com inúmeras situações conflituosas do dia-a-dia nas empresas.

Nesse aspecto, observei que a saúde emocional e a qualidade de vida do trabalhador pode ir além de um conceito fundamental, pois é um fator importante para as empresas que visam proporcionar aos funcionários uma proposta de promoção e prevenção de saúde, com ações que favoreçam aos trabalhadores com programas de saúde metal, atividades para alívio do estresse e cansaço nas intensas horas de trabalho. Houve dificuldades para analisar nos contos alguns pontos que delineavam a QVT, sendo que em alguns contos foi possível a reflexão sobre o trabalho e seus aspectos positivos, no modo como o conduziam em um determinado contexto.

Considero, a partir disto que, nos contos apresentados, ocorreu uma descrição precária das questões de programas de qualidade de vida no trabalho e critérios específicos das necessidades profissionais e humanas dos trabalhadores. Houve também, a tentativa de se analisar nos contos possíveis propostas de melhorias com relação aos programas de QVT, em que as empresas sutilmente tiveram a ideia de propor e ampliar seus programas. 
No entanto, verifiquei poucas execuções destes programas de qualificação dos trabalhadores mais efetivamente nas organizações. Com isso, foi possível encontrar alguns discursos com conflitos pessoais e profissionais que relatam, principalmente, situações da ausência de qualidade de vida no trabalho, prejudicando, muitas vezes, a saúde do trabalhador.

A partir dos aspectos psicológicos, compreendo que nos contos a Qualidade de Vida no Trabalho, o sentimento do gostar do que se faz e a forma de colaborar com a melhoria das questões do trabalho podem ser fundamentais para o trabalhador, pois este, ao dedicar várias horas de trabalho, reconhecesse nos discursos a valorização e o amor pelo que fazem na vida profissional, independente do cargo que ocupam na empresa.

Nesse sentido, posso inferir que o mundo do trabalho, apesar da falta de QVT pode ser recompensada por pequenos gestos e elogios das pessoas que se reconhecem neste mundo do trabalho, como uma questão de prioridade e fidelidade ao processo de profissionalismo.

Com relação aos aspectos físicos e sociais, percebi que os trabalhadores da maioria dos contos analisados negam o adoecimento do mundo do trabalho e não percebem isto como fator importante a ser tratado. Por exemplo, no uso dos medicamentos, relatado em alguns dos contos, aparece o fator da negação e de reconhecimento do adoecimento pelo excesso de trabalho, completando com a negligência das empresas nos principais aspectos da relação trabalhador e empresa.

Por fim, a reflexão crítica positiva que consiste em persistir nos contos é em alguns aspectos ausentes, pois nos possibilita verificar o quanto ainda falta nas organizações uma gestão que possa reforçar e ampliar as ações e as atividades, que promovam conscientização de saúde física e mental, bem estar, ambiente 
tranquilo e mais qualidade de vida aos funcionários, nas diferentes situações de contextos das empresas.

Desta forma, este trabalho apresentou uma maneira de abordar a análise de conteúdo nos contos, que não devem ser consideradas conclusiva, mas uma forma de refletir sobre as modificações no mundo do trabalho, que possam interferir na Saúde do Trabalhador e na Qualidade de Vida no Trabalho em diferentes contextos. Sugiro estudos científicos que possam averiguar e auxiliar gestores, empresas e funcionários sobre a saúde mental e qualidade de vida no trabalho em um mundo cada vez mais exigente.

Nesse sentido, a carência de publicações, por parte de profissionais educadores, psicólogos organizacionais e do trabalho, administradores, acadêmicos, faz com que o próprio trabalho desenvolvido nas organizações não alcance possíveis êxitos esperados. Mas a temática não está esgotada, uma vez que podemos observar a importância das profissões, mas, principalmente, dos sujeitos profissionais que se formam nos bancos escolares.

O que a educação pode contribuir para desenvolver novos profissionais e profissões? O que muda na atual educação para a qualidade de vida no trabalho?

As publicações desses resultados para a comunidade acadêmica e cientifica são de muita relevância para o desenvolvimento das profissões e dos vários profissionais que possam impactar o mundo do trabalho com excelência, e também maior qualidade de vida para exercerem suas funções e ações profissionais. 


\section{REFERENNCIAS}


BALDINI, R. De L.; Tíra o pé da minha marmita! entendendo e administrando conflitos na empresa. Qualitymark, Rio de Janeiro, 2013.

BARBOSA, C. A.; Trabalho e vida pessoal: 50 Contos selecionados: executivos, administradores e operários compartilhando suas experiências de vida. Qualitymark, Rio de Janeiro, 2003

BARDIN, L. Análise de conteúdo. Lisboa: Edições 70; 1977.

BAUMAN, Z. Identidade. Rio de Janeiro; Zahar, 2005.

BORGES, L. O.; MOURÃO L.; O trabalho e as organizações. Atuações a partir da psicologia. Porto Alegre. Artmed, 2013.

CARDOSO, A. C. M.; O trabalho como determinante do processo saúde-doença. Tempo social, revista de sociologia da USP, v.27,n.1. 2015. Disponível: <http://www.scielo.br/pdf/ts/v27n1/0103-2070-ts-27-01-00073.pdf>

CODO, Wanderley; Educação: carinho e trabalho. Editora vozes. Brasília, 2006.

CHIAVENATTO, I. Gestão de pessoas: o novo papel dos recursos humanos nas organizações. 4 ed. SP: Manole, 2014.

CHIAVENATTO, I. Recursos Humanos. 6. ed. compacta. São Paulo, SP: Atlas, p. $631,2000$.

DEJOURS, C.; A loucura do trabalho: estudo de psicopatologia do trabalho. Tradução: Ana Isabel Paraguay, Lucia Leal Ferreira. 6 ed. Cortez. São Paulo, 2015

DOLAN, S.; Estresse, auto estima, saúde e trabalho. tradução J. Simões. Rio de Janeiro: Qualitymark, 2006.

FERNANDES, E. C.; Qualidade de vida no trabalho. 6 ed. Casa da Qualidade, Salvador, BA ,1996 
FERRAZ, L. Conto popular, estória oral e conto literário: uma análise intertextual. Estudos Linguísticos, São Paulo, 43(3): p.1356-1370, set-dez.2014. Disponível em: <https://revistas.gel.org.br/estudos-linguisticos/article/viewFile/529/404>

FERREIRA, I.F. Clima Organizacional e qualidade de vida no trabalho. ORG. Andrea Ramal. - MBA: Gestão de Pessoas. Rio de Janeiro: LTC, 2013.

FERREIRA, M.C.; Qualidade de Vida no Trabalho. Uma Abordagem Centrada no Olhar dos Trabalhadores. Brasília, DF: Edições Ler, Pensar, Agir,2011.

FREITAS, Leda G. Prazer e sofrimento no trabalho docente: pesquisas brasileiras. Curitiba: Juruá, 2013.

GIL, Antônio C.; Como elaborar projetos de pesquisa. 4ed. São Paulo: Atlas, 2002

GOLDENBERG, P. (Org.) O Clássico e o Novo: tendências, objetos e abordagens em ciências sociais e saúde / Organizado por Paulete Goldenberg, Regina Maria GIFFONI MARSIGLIA, M. H. Andréa Gomes. Rio de Janeiro: Editora Fiocruz, 2003. Disponível:<https://static.scielo.org/scielobooks/d5t55/pdf/ goldenberg-9788575412510.pdf>

HOVERD, B.; Sob pressão: tática que funcionam para transformar estresse em resultado. São Paulo: Editora Gente, 2015.

HUSSERL, Edmund. La crise des sciences européennes et la phénomènologie transcendentale. Trad. De Gerard Granel. Paris: Edittrice CLUEB, 1986.

JOSSO, Marie C.; Experiências de vida e formação. São Paulo. Editora: Cortez. 2004.

LIMONGI-FRANÇA, A.C. Qualidade de vida no trabalho - QVT: conceitos e práticas nas empresas da sociedade pós-industrial. 2ed. - 6 reimpr. - São Paulo: Atlas, 2010.

MINAYO, M. C. de S.; (org). Pesquisa Social: teoria, método e criatividade. 28 ed. Petrópolis, RJ: Vozes, 2009 
MOISES M.; A Análise Literária. 16 ed. São Paulo, Editora Cultrix, 2007

MOSER D. A.; KERBING R. O conceito de saúde e seus desdobramentos nas várias formas de atenção à saúde do trabalhador. Fisioterapia em movimento, Curitiba, v19, n4, p. 89-87, out./dez.2006.

NASCIMENTO L.; Gestores de pessoas: os impactos das transformações no mercado de trabalho. Rio de janeiro: Qualitymark, 2006.

OLIVEIRA, P. M.; LIMONGI- FRANÇAA. C.; 2005 Avaliação da gestão de programas de qualidade de vida no trabalho. RAE -eletrônica, v. 4n. 1, Art.9, jan./jul. Disponível: <www.rae.com.br/eletrônica>

ORGANIZAÇÃO INTERNACIONAL DO TRABALHO. (OPAS) Disponível em $<w w w . o p a s . g o v . b r>$.

RIBEIRO, L.A.; SANTANA, L.C.; Qualidade de qualidade de vida no trabalho: fator decisivo para o sucesso organizacional. Revista de Iniciação Científica RIC Cairu. Jun. 2015, Vol. 02, nº 02, p. 75-96.

REY, Fernando G.; Personalidade, saúde e vida. São Paulo. Editora: Pioneira. 2004.

SANT'ANNA, A. S., KILIMNIK, Z. M. (Orgs). Qualidade de vida no trabalho: abordagens e fundamentos. Rio de Janeiro: Elsevier; Belo Horizonte, MG: Fundação Dom Cabral. 2011.

SARTAIN, D.; KATSAROU M.; Sob pressão: como compreender e administrar a pressão e o estresse no trabalho. Tradução: Sérgio Rosenwald. Rio de Janeiro: Qualitymark, 2012.

SERRA, F.; Demitido: quando é preciso tirar a camisa. Rio de Janeiro: Qualitymark, 2010

SILVA, U. L.; OLIVEIRA, Á. de F.; Qualidade de Vida e Valores nas Organizações: Impactos na Confiança do Empregado. Psicologia. Ciência e Profissão. Brasília, v. 37, n. 1, p. 7-17, jan. 2017. 
SIMIONATO, M. A.; O fator emocional nas negociações: criar um ambiente construtivo nas relações. Rio de Janeiro, Qualitymark, 2011

SIQUEIRA, M. V.S.; Gestão de pessoas e discurso organizacional. 2ed. Curitiba; Juruá, 2009.

SPECTOR, P. E. Psicologia das organizações. 4ed. São Paulo: Saraiva, 2014.

VASCONCELOS A. F. Qualidade de vida no trabalho: origem, evolução e perspectivas. Caderno de Pesquisas em Administração, São Paulo, v.08, n 1 , janeiro/março 2001.

ZANELLI, J. C.; Estresse nas organizações de trabalho: compreensão e intervenção baseadas em evidências. Porto Alegre: Artmed, 2010.

ZANELLI, J. C.; Psicologia, Organizações e Trabalho no Brasil. 2ed. Porto Alegre: Artmed, 2014 


\section{SOBRE A AUTORA}

\section{Maricélia de Almeida Vieira}

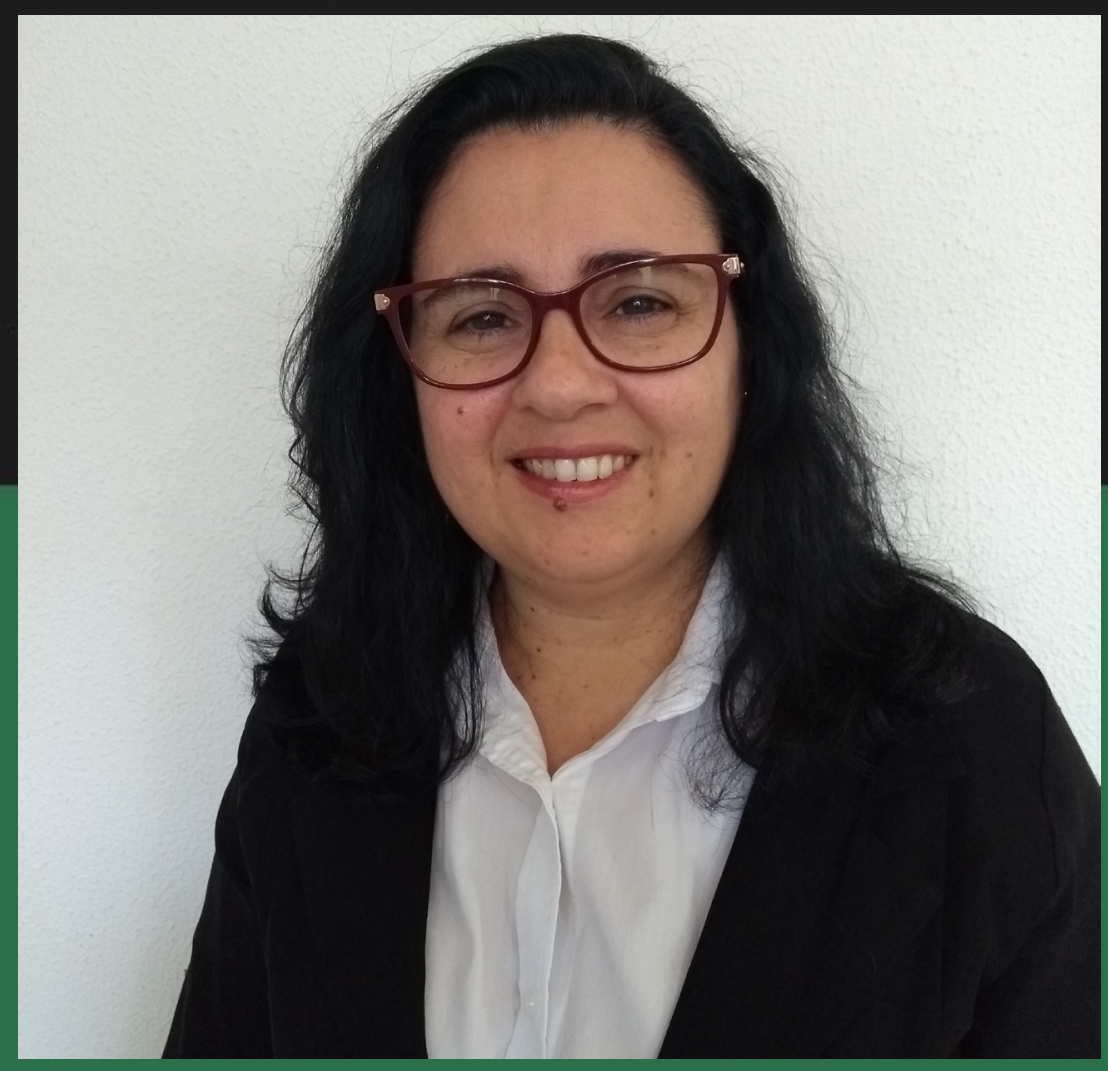

Docente da Faculdade Integrada de Santa Maria-FISMA, nos cursos de Graduação em Administração, Psicologia e Enfermagem e no Curso Técnico em Enfermagem em Língua Portuguesa. Graduada em LetrasPortuguês formada pelo Centro Universitário Franciscano (2004). Formada em Psicologia pela Universidade Franciscana-UFN (2018), com registro no Conselho Federal de Psicologia sob nr. 07/29368. Especialista em Língua Portuguesa pelo Centro Universitário Franciscano (2006) e em Mídias na Educação pela Universidade Federal de Santa Maria-UFSM (2018). Mestre em Educação pelo Programa de Pós Graduação em Educação da Universidade Federal de Santa Maria - PPGE-UFSM. Possui experiência ampla como tutora a distância no Curso de Graduação em Letras da UFSM - EAD. O campo de pesquisa está direcionado para Formação Docente, Qualidade de vida no trabalho, Educação Superior, Saúde Mental dos profissionais em Educação e no Ensino em Educação a Distância-EAD. 
www.arcoeditores.com

contato@arcoeditores.com

(5)arcoeditores

larcoeditores

$(55) 99723-4952$
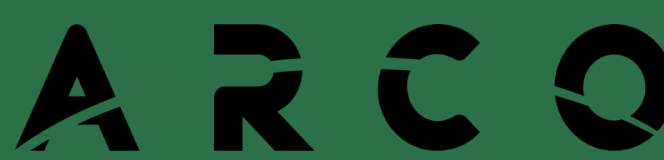

E D I TORE S 